\title{
Dazhbog: The Ancient Slavic Pagan Deity of the Shining Sky
}

— Oleg V. Kutarev $\overline{ }$

Prispevek podrobno obravnava enega najbolj znanih in pogosto omenjenih slovanskih poganskih božanstev, tj. Dažbog (ali Daž(d)bog). Obravnava izpostavlja in problematizira določene zgodovinopisne stereotipe, ki so polni nasprotij in težav. Na primer: 1) opredelitev Dažboga kot božanstva sonca; 2) njegova bližina drugemu sončnemu božanstvu, Horsu, in nejasnost, zakaj naj bi obstajali dve sončni božanstvi; 3) Dažbogov odnos do božanstva Svaroga oz. Svarožiča; 4) Dažbogova pripadnost samo vzhodnoslovanskemu območju; 5) etimologija njegovega imena kot »dajanje božanstva«. V tem prispevku je podan alternativni, pogosto spregledan pogled na Dažboga, ki lahko reši te težave.

KLJUČNE BESEDE: slovansko poganstvo, Dažbog, Svarog, Dabog, Hors, indoevropska mitologija
The paper is concerned with a detailed consideration of one of the most well-known and frequently mentioned Slavic pagan deities: Dazhbog (or Daž(d)bog). Historiographic stereotypes full of contradictions and problems have been fixed in research concerned with the deity, for example, defining Dazhbog as the deity of the sun; its proximity to another solar deity (Chors) and vagueness, why are there two solar deities; Dazhbog's relation to the deity Svarog/Svarozhich; Dazhbog's belonging only to the East Slavic area; the etymology of his name as a "giving deity". An alternative view on Dazhbog (overlooked rather than new) that can solve these problems is given in this paper.

KEYWORDS: Slavic paganism, Dazhbog, Svarog, Dabog, Chors, Indo-European mythology

\section{INTRODUCTION}

This paper is a revision of my two earlier papers published in Russian in 2015-2016 (Кутарев 2015; Кутарев 2016b); ${ }^{1}$ both of them are publicly available in electronic form (see References). In the first article, I have considered earlier insufficiently explored aspects of the sources of the South Slavic origin on the Slavic pagan deity Dazhbog and the character of Serbian folklore Dabog. In the second one, I have carefully proposed a theory, according to which Dazhbog could functionally be not so much a deity of the sun (as he is usually treated) as more likely an evolution of the Indo-European image of

1 I would like to express my gratitude for assistance in translation of this article into English to Ksenia Alieva. 
the Sky Deity. In the course of the subsequent discussions and further work, I have been convinced of the high probability of such an approach, and now I am drawing up this paper in a polemical manner, generally objecting to the fixed view on Dazhbog as the deity of the sun. Some other historiographic stereotypes are also objectionable.

When considering the textual sources on the Slavic paganism (at least those relating to the higher mythology), one may notice that all of them were well-known to scholars as far back as the second half of the $19^{\text {th }}$ century ${ }^{2}$ (Гейштор 2014: 37). Therefore, it is also necessary to turn to other fields of knowledge, which can provide new facts to aid in becoming acquainted with Slavic culture. Along with archaeology, folklore, and ethnography, comparative religious studies and linguistics are also of the greatest importance in this context. At the same time, it seems that the potentialities of textual analysis of the ancient sources are also by no means exhausted.

\section{DAZHBOG IN ANCIENT SOURCES}

Dazhbog has been mentioned in independent medieval sources only among the texts of the Old Russian literature (see below). The development of this literature started soon after the Christianization of the Rus in 988. The "Primary Chronicle", the earliest extant Old Russian chronicle, was completed ca. 1118 (although its origins go back to the second half of the $11^{\text {th }}$ century). Today it is known for two main editions, of which the earliest records have named the Laurentian Codex (the second half of the $14^{\text {th }}$ century) and the Hypatian Codex (early in the $15^{\text {th }}$ century). The difference between the editions is not great but has significant for researching Dazhbog.

In the extract concerned with the events of $980,{ }^{3}$ the Primary Chronicle reports ${ }^{4}$ that prince "Vladimir began to reign in Kiev alone, and put the idols on the hill behind the palace yard: wooden Perun with a silver head and golden moustache, and Chors, and Dazhbog, and Stribog, and Semargl, and Mokosh. And sacrifices were made to them, with calling them the deities” (БЛДР 2000: 126-127; Лавр. 1926: стб. 79; Ипат. 1908:

\footnotetext{
2 Perhaps only individual records and editions of the texts previously known belong to the number of new findings. Although the authors Słupecki and Zaroff, who supposed that they had discovered the previously unknown source on the Slavic paganism, the brief article on fortune-telling in West Slavic Lutici tribe (Stupecki, Zaroff 1999: 9), have disputed against this thesis in the second volume of Studia Mythologica Slavica, in fact, as far back as 1872 Kotliarevsky researched this data of William of Malmesbury "discovered" by them (Кирпичников 1885: 62 прим. 1).

3 The Byzantine era, "Constantinople era", prevailed in Rus until 1700, the era having counted the years "from the creation of the world" (according to the biblical mythology). The first year of that era was 5508 B.C., thus, 980 is marked as $6488(5508+980)$ in the original of the chronicle, etc. Only the contemporary era will be used below for convenience.

4 Herein English translation of the Primary Chronicle is based on Tvorogov's translation from Old Russian into modern Russian according to the edition (БЛДР 2000). However, I remove the spelling "Dazhdbog" (containing two letters "d") from this translation, since it is almost always "Дажьбогъ" ("Dazhbog") in the original of the Primary Chronicle. Each quotation from the Primary Chronicle is also accompanied by the references to the original Old Russian text according to the editions and text markup in the academic series "Complete Collection of Russian Chronicles" (Лавр. 1926; Ипат. 1908).
} 
стб. 67). ${ }^{5}$ The reader can see the description of the most important religious sanctuary of pre-Christian Rus in its then capital Kiev and, correspondingly, its most significant deities (with some reservations, though, which go beyond the research into Dazhbog). Unfortunately, the ecclesiastical author has not thought of describing the deities mentioned in more detail, although in his time, the Russian reader certainly still knew them rather. In 988, when christening Rus, same Vladimir "ordered to throw down the idols: some of them to chop, and others to burn down", ${ }^{6}$ and after the descriptions of ritual desecration and expulsion of Perun idol (БЛДР 2000: 130-131, 160-163; Лавр. 1926: стб. 82-83, 116-117; Ипат. 1908: стб. 69-70, 101-102) the Primary Chronicle does not refer to any of the deities mentioned any more, except for Dazhbog. ${ }^{7}$

He quite unexpectedly appears with his father Svarog in the record on the year 1114 in the Hypatian Codex (there is nothing of the kind in the Laurentian Codex). ${ }^{8}$ Here, following the information about the rains of the glass beads and even of squirrels and deer, the author, foreseeing the reader's scepticism, adds: "if someone does not believe in it, let him/her read the Chronograph". Then a mythological plot is recited about the fact as during the reign of Pheosta in Egypt (a corrupt name of the Greek blacksmith god Hephaestus) "that was called Svarog by the Egyptians", the smith tongs fell from the heavens, which resulted in the origin of metallurgy. Pheosta-Svarog had also introduced monogamy: a law under which a man could have only one wife, and a woman could have only one husband; "if anyone violates this law, let him/her be thrown into a fiery furnace". "The Sun-king, Svarog's son, or Dazhbog" ruled after him, who, having heard of one woman's betrayals, caught her in the act. When he beheaded the man who was with her and started to take her "over the Egyptian land to shame" (note that no throwing into a furnace takes place), a good time came to the country, and "everybody praised him"9 (БЛДР 2000: 308-311; Ипат. 1908: стб. 277-279).

In fact, the sudden appearance of Slavic deities among the Egyptian rulers is not a paradox. After Christianization, the following conceptions appeared in Roman and Greek

\footnotetext{
5 Original (Hypatian Codex): “нача кн^жити Володимиръ въ Києвъ шдинъ. и постави кумиры на холъму. внњ двора теремнаго. Перуна деревАна. а голова єго серебрАна. а оусъ золотъ. и Хоръса. и Дажьбога. и Стрибога. и Сњмарьгла. и Мокошь. и жр^хут имъ. наричуще богы”.

6 Original (Hypatian Codex): “повель кумиры испроврещи. швы исъщи. а другыя шгньви предати”.

7 Certainly, paganism did not vanish in Rus in 988 in a moment; dvoeverie ("two beliefs": “две веры”, paganism and Christianity) remained here until the $13^{\text {th }}-14^{\text {th }}$ centuries, and this period Christianity, on the one hand, struggled against, and, on the other hand, adopted the elements of paganism that generally continued to vanish. It is most significant that in the same 1110s, when the Primary Chronicle was being created, the Vyatichi pagans (one of the East Slavic tribes) murdered Kupsha, better known as Kuksha of the Kiev Caves, for preaching Christianity. However, the author of the chronicle ideologically aimed at not referring to the paganism after its official leaving (Кутарев 2016a: 136).

8 See the article (Kutarev 2021) for the most detailed analysis of this extract from the Primary Chronicle, as well as all its sources in the original and in translation into English, in fact representing the appendix to this paper and being available in electronic form. It is important that it also discusses the mistakes of frequently used historiography, for example, those of Mansikka.

9 Original: “аще ли кто сему въры не иметь. да почнеть фронографа [...] Феоста иже. и Соварога. нарекоша ЕгуптАне [...]. аще ли кто переступить да ввергуть и в пещь огнену. сего ради прозваша и Сварогомъ. [...] Солнце царь сынъ Свароговъ. еже есть Дажьбогъ бъ бо мужь силенъ. [...] пусти ю водити по земли в коризнъ. [...] и бысть чисто житье по всей земли. Егупетьскои. и хвалити начаша".
} 
literature: firstly, the old pagan deities widely known by myths and popular legends were merely outstanding people (sometimes magicians) of antiquity; ${ }^{10}$ secondly, these people were frequently descended from ancient biblical characters. The Byzantine author John Malala also worked in this way in the $6^{\text {th }}$ century, before whom a task was set to create a united world history, taking into account Graeco-Roman and biblical mythological heritage. In his work "Chronographia" (created ca. 560s) about Hephaestus's rule in Egypt and Helios-Sun after him, he gave them the roles of cultural heroes but reducing them from gods to people. Then, shortly after the Christianization of South Slavs (Bulgarians and Macedonians), in the $9^{\text {th }}$ to $10^{\text {th }}$ centuries, these peoples began to translate the Byzantine works from Greek into Slavic, including the historical ones. Thus, "probably, as far back as X century", "by I. I. Sreznevsky's hypothesis, [Malala's "Chronographia”] turned out to be translated [into Old Slavonic from Greek] in Bulgaria"11 (Творогов 1987: 472). However, this and many other translations were not preserved in Bulgaria or other South Slavic countries; we are aware of them only because these Old Slavonic sources were brought or copied in Russian cloisters after the Christianization of the Rus. It is this text that the author of the Primary Chronicle had in the $12^{\text {th }}$ or $13^{\text {th }}$ centuries, and it is this text that he mentioned: "let him/her read Chronograph". This refers to the Old Russian compilation comprised of Byzantine sources (among which also was Malala's "Chronographia") translated into Slavic and setting forth the ancient history (Творогов, 1983; Истрин 1994: 14-15). Several such compilations-chronographs are extant.

It is highly significant that "contrary to diffused opinion" (БЛДР 2000: 523-524), "identification of Hephaestus with Svarog, and Helios (Sun) with Dazhdbog", which we are interested in, "does not belong to the author of the compiled Russian chronograph [...], never mind the chronicler, who had included the extract from Malala's Chronographia in the annalistic article of 1114 [...], but it goes back to some ancient (if not the original) version of the translation of Malala's Chronographia" (Творогов, 1983: 191), which made in Bulgaria. Indeed, although, for example, a prominent researcher of Slavic paganism (and the Middle Ages in general) Łowmiański frankly and convincingly wrote that, in this case, we could see the source "relating to the higher mythology of the South Slavs (rather than the East Slavs as it is almost everywhere commonly believed)" (Ловмянский 2003: 75); this opinion not infrequently remains unnoticed; Dazhbog and Svarog are constantly referred to as "East Slavic=Old Russian" deities, ${ }^{12}$ although it is the South Slavic scribe that had replaced the Greek names by the names from Slavic mythology. There is no doubt that the scribe had done that to explain the mythological function: ${ }^{13}$ the Greek god of fire, Hephaestus, could be unknown to the Slavic reader, but the deity of fire, Svarog,

\footnotetext{
10 This approach is called euhemerism.

11 The most prominent researchers of Malala's Slavic translation, Istrin and Tvorogov, and many others subsequently adhered to the same version of the translation's place of origin.

${ }_{12}$ In many respects, due to still prevailing authority of Jagić, Brückner, and Mansikka (Ловмянский 2003: 77-78), the authors undoubtedly standout in other works on Slavic paganism. However, it is that their view that should be rejected now as the obsolete one.

${ }^{13}$ Some similar examples of "translation" of Greek gods into Slavic ones are known in the Old Russian literature, see for them (Kutarev 2021: 111-112 ft. 26).
} 
was clear for him/her (see below). Meanwhile, the name "Svarog" is never mentioned in independent East Slavic sources (Ловмянский 2003: 78). ${ }^{14}$

The analysis of sources shows that the text of the Primary Chronicle retells Malala's "Chronographia" quite close to the original (Kutarev 2021: 114-119); the Slavic scribes had added only several independent fragments, in fact representing just two nuances. Firstly, the names: Pheosta-Hephaestus became Svarog, and his son (Helios in the original; "Sun" in Slavic translation) Dazhbog; this correction was made by the South Slavic scribe. Secondly, a way of punishment for betrayal introduced by Svarog: being cast into a fiery furnace, having been written in the Primary Chronicle by the Old Russian author. ${ }^{15}$ Everything else (Egypt; smith tongs fallen from the heavens; establishment of the institution of marriage and punishment of betrayers by successful son-ruler) was taken from Malala by the Slavic scribes without any change. However, one more important point should be noted here: having come across the South Slavic glosses on Svarog and Dazhbog, the Old Russian author of the Primary Chronicle did not correct or remove them; he used them, which undoubtedly points to the fact that they were clear to him and those readers for whom he was writing. It is particularly obvious in the case of Dazhbog that was mentioned in the Primary Chronicle earlier regardless of external sources. Thus, Dazhbog appears as a deity of both the South and East Slavs, which undoubtedly points to his significance and probable proto-Slavic origin. A Bulgarian of the $10^{\text {th }}$ century and a Russian of the $12^{\text {th }}$ century did not need an explanation of who he was.

The Sermons against Pagans give another ancient corpus of references to the Slavic deities. This genre also originates from Byzantine literature, and it was also partially influenced by the South Slavs. Thus, one of the most significant Sermons against Pagans, "The Sermon on Idols", ${ }^{16}$ has the following lines: "[...] and the Slavs create and make sacrifice to the deities; to Vilas, and Mokosh, Diva, Perun, Chors, Rod, and Rozhanica, Upyrs, and Bereginias, and Pereplut, and revolving, they drink from drinking horns [in] his [honour], and pray to Fire Svarozhets, and arranged a bath for the Navys"17 (Гальковский 2013: 287). Mokosh (and her epithet Diva? or is it an individual deity?), Chors and Perun have already occurred in the Primary Chronicle in the list of the supreme deities of Rus;

\footnotetext{
14 Though a word "svarog" is known in Novgorod dialects as the old name for fire, as well as "cricket" ("сверчок"), grasshopper (СРНГ 2002: 214), which in Russian literally means a "small blacksmith" (“кузнечик”). Speaking of Łowmiański's concept as a whole, with considering its idea of Slavic primitive monotheism headed by Svarog-Perun, it is difficult to accept it, see for example (Гейштор 2014: 281-282; Кутарев 2018: 115-120).

15 The fact that these fragments have various origins is evident from the Slavic translation of Malala's "Chronographia" that "was collected bit by bit by V. M. Istrin from chronographs and chroniclers", mainly from Russian records of the $15^{\text {th }}$ and $16^{\text {th }}$ centuries; its full single text has not been preserved (Истрин 1994: 9). There are substitute names here (only in the chapters relating to book II), but there is nothing about the furnace.

${ }_{16}$ The accepted short abbreviation of the name is quite explainable, for its full name is "The Sermon of St. Gregory [the Theologian] created while interpreting how formerly peoples, being the pagans, worshipped idols and made sacrifices to them, which they are doing now as well". A number of key versions of this Sermon appeared within a period from the $11^{\text {th }}$ to $13^{\text {th }}$ centuries (Письменные памятники 2003: 155) was published by Galkovskij (Гальковский 2013: 281-300).

17 Translation of the Sermons against Pagans from Old Russian here and hereinafter is mine. Original: “богомъ требоу кладоуть и творАть. и словеньскыи языкъ. вилам. и мокошьи. дивъ. пероуну. хърсоу. родоу. и рожаници. оупиремь. и берегынАмъ. и переплутоу. и вертАчесА пьютъ емоу въ розЊхъ. и шгневи сварожицю молАтсА. и навьмь. мъвь творАть".
} 
mysterious Pereplut must also belong to the deities. Rod and Rožanica (nevertheless, Rožanicy are usually referred to in plural) are the deified ancestors and grantors of the fates (Kutarev 2019). Upyrs are a prototype of Vampires (these words must be cognate); Bereginias are the spirits of dead babies (Гальковский 2013: 297). Navys are the dead ancestors whose spirits, according to popular beliefs, come to the living on certain days; at that time, all accessories for washing were left for them in a bathhouse. Vilas are more interesting to us: as is not infrequently noted, these beautiful female spirits have South Slavic origin, which may point to the original stage of existence of this text, for example, in Serbia (Гальковский 2013: с. 284). Moreover, according to this text and other Sermons against Pagans, it is also possible to obtain additional materials to analyse the image of Svarog: the concepts of "Fire" and "Svarozhets" are directly identified with each other here. The second of two most important Sermons against Pagans considered to be the most ancient: "The Sermon of man who loves Christ"18 of the $11^{\text {th }}$ century (Письменные памятники 2003: 153) is also aware of Fire Svarozhets. It says: “[...] those who believe in two different religions, believe in Perun and Chors, and Mokosh, and Sim and Rgl, and Volys that are 30 sisters in number. Boors say so, and regard all that as [gods and] goddesses, and, therefore, make offerings to them, and slaughter roosters [in sacrifice] to them. They pray to Fire, calling it Svarozhets, and take garlic as a deity"; at the same time, they "pray to" fire "in drying barn"19 (Гальковский 2013: 305, 307). "Volys" is a misspelling of "Vilas"; little-known Semargl mentioned in the Primary Chronicle has split into two parts. Svarozhets is again directly specified as Fire. This name is more frequently conveyed as Svarozhich in studies; there is such a spelling in the sources, although the very diminutival suffix -ets ${ }^{20}$ prevails (cf. modern Russian: братец (bratets) "[little or beloved] brother" [brat]; столбец (stolbets) "small column" [stolb], etc.).

Seemingly, this consideration distracts us from Dazhbog, but it will be clear further why it has been provided. Let me note that there is no Dazhbog (nor Stribog) in early versions of Sermons against Pagans, although the rest of the full list of the Kiev pantheon from the Primary Chronicle has been provided in "The Sermon of man who loves Christ" (only Mokosh goes before Semargl here, and the latter is "bifurcated"), but it is easy to explain. "A word 'Bog' (God) is misused in these names" that could have a wrong connotation within the Christian enlightenment, for only Christian God could be referred to as God after Christianization, and the pagan deities were considered demons (Мансикка 2005: 138; ср. Васильев 1999: 111). ${ }^{21}$ Only the latest $\left(16^{\text {th }}\right.$ century) version

\footnotetext{
18 The most famous version of the full name: "The Sermon of man who loves Christ, and Adherent of the True Faith".

19 Original: “двое върно живущих върующе в перуна и хорса и въ мокошь и в Сима и въ Рьгла и въ волы их же числомъ. Л сестрђниць. глаголють бо невъгласни то все мнАть богынАмі и тако покладывають имъ требы. и куры имъ ръжуть. шгневи сА молАть. зовуще его сварожицемь и чесновитокъ богомъ творАть", “молАть подъ швиномъ”.

${ }^{20}$ The versions of spelling the name according to "The Sermon on Idols", "The Sermon of man who loves Christ”, and “The Sermon of Chrysostom”: сварожицю, въ сварожитьца, сварожицем(ь) (in two editions), сварожичемъ, сварожичьмъ, въ сварожица (Гальковский 2013: 287, 297, 305, 309); i.e., the form of -ец (-ets)/-иц (-its) occurs much more frequently than -ич (-ich). Other sources do not have it.

${ }^{21}$ There is every reason to believe that basically not so much frequent occurrence of Dazhbog in the sources as might be expected may be also explained by the same thing.
} 
of "The Sermon on Idols" separately "recalls" that "other people believe in Stribog, and Dazhbog, and Pereplut"22 (Гальковский 2013: 299). This point must be quoted (literally, with only omitting conjunction "and" following "Stribog") from the Sermon against Pagans "The Sermon of Chrysostom"23 (Гальковский 2013: 324), dating from the $13^{\text {th }}$ century (Письменные памятники 2003: 159). There is no Dazhbog in other Sermons against Pagans.

The last important source mentioning Dazhbog is a short (shorter than this paper) epic poem "The Tale of Igor's Campaign" created ca. 1185 and represents a masterpiece of the Old Russian Middle Ages. None of the other works has been likely to be translated and adapted so often in the whole of Russian literature; the source has been explored exhaustively. Although as far back as the middle of the $20^{\text {th }}$ century, it was possible to come across the view that "The Tale of Igor's Campaign" is a hoax created in the $18^{\text {th }}$ century or shortly before; at present, it is absolutely impossible to state that (Зализняк 2008) despite the fact that the original of the only record was lost in the Fire of Moscow caused by Napoleon in 1812. Despite their quite late time of creation, the pagan images used exclusively in an artistic sense appear in unexpected abundance in "The Tale of Igor's Campaign" (which raised doubts about the authentic antiquity of the text). For example, the phrase (СПИ 1985: 38): "the winds, Stribog's grandchildren, waft from the sea"24 suggested that Stribog was related to atmospheric phenomena. The functions of one more supreme Old Russian deity known for the Primary Chronicle and the Sermons against Pagans are also explained on the basis of the text of "The Tale of Igor's Campaign": "Prince Vseslav held court for people, assigned the princes to the towns, while prowled as a wolf at night: he prowled from Kiev to Tmutarakan ${ }^{25}$ until dawn, crossed great Chors's path as a wolf"26 (СПИ 1985: 42-43). Thus, great Chors appears as a deity of a heavenly body. Strange though it may seem, there is no Perun in "The Tale of Igor's Campaign", but Dazhbog appears twice, both times are in the phrase "Dazhbog's grandchildren", ${ }^{27}$ while it is not quite clear, to whom exactly it is referring. It is usually supposed that it refers to either the Russian princes or the Russian people in general. It seems that this issue has not been still resolved, and the researchers disagree. For more information, see very broad historiography of the issue (Соколова 1995: 80-81).

\footnotetext{
22 Original: “дружии въроуть въ стрибога. и дажьбога. и переплоута”.

${ }^{23}$ Full name: "The Sermon of our Father, John Chrysostom, Archbishop of Constantinople, about how pagans believed in idols before, and made sacrifices to them, and called their names, which many people are doing now as well, being Christians, but without knowing what Christianity is".

${ }^{24}$ Herein and hereinafter English translation is based on Tvorogov's translation from Old Russian into modern Russian according to the edition (СПИ 1985); and the original text is quoted according to the first edition of “The Tale of Igor's Campaign”: “вътри, Стрибожи внуци, въютъ съморя” (СПИ 1800: 12).

${ }^{25}$ Nowadays it is Taman, a small town in the South of Russia, wherefrom the Crimean Bridge stretches to the Crimea.

26 Original: “Всеславъ Князь людемъ судяше, Князьмъ грады рядяше, а самъ въ ночь влъкомъ рыскаше; изъ Кыева дорискаше до Курь Тмутороканя; великому хръсови влькомъ путь прерыскаше” (СПИ 1800: 36).

27 Original: "погибашеть жизнь Даждь-Божа внука" and “въстала обида въ силахъ Дажь-Божа внука" (СПИ 1800: 16-17, 19) in the sense of "some person dies" and "some person took offence".
} 
There are no other important textual sources on Dazhbog. Surely he has more than once appeared in the Old Russian literature, but generally those were the quatiotions from the Primary Chronicle that were less understood and more distorted by the authors. For example, the source of 1560s "Степенная книга" (Book of Royal Degrees) described the Christianization of Rus in 988 as follows: the statues of "Perun and Chars, and Toad and Mokosh, and Vlasiy, the deity of cattle, and other idols"28 were smashed (Степенная книга 1775: 138). It is evident that Dazhbog's name was understood as two words, where the former is copulative "да" ("and"), and the latter is “жаба" ("toad" by consonance), Stribog and Semargl were rejected, and Mokosh's name was interpreted as the male one. At the same time, Volos's name was made into Vlasiy, ${ }^{29}$ and his description as the deity of cattle was taken from another passage of the Primary Chronicle. Many similar examples may be given (Kutarev 2021: 107-109). All this points to the fact that the Russian pagan pantheon at the Modern Age was described merely as some literary rather than ethnographic tradition.

The material of onomastics and especially folklore can add the data of textual sources. Thus, it is noted that “the [people's] names Dadibog, Dadzibog(-ius), Daczbogius occur in the Polish documents of the $13^{\text {th }}-14^{\text {th }}$ centuries, Dadzibog Maskiewicz was among the students of the Kyiv-Mohyla Academy in Kiev in XVII century, cf. 'Danilo Dazhbogovich Zaderevetskiy, the dweller of the Russian land' in Galicia (1394)" (Васильев 1999: 70). Folklore is also familiar with Dazhbog: he is mentioned in several Novgorod proverbs, for example: "pray to Dazhbog, he will help a little", and similar. (Соколова 1995: 79). The words "Dazhbo", "Dazhba" in some regions could be understood as "indeed" up to the $19^{\text {th }}$ century, for example, "here is Dazhba, burst the eyes" in Ryazan, "Dazhba from God grant” (Мансикка 2005: 295; Клейн 2004: 241-244).

Apart from personal names that may presumably originate from Dazhbog's name and are spread among all three branches of the Slavs, some similar geographical names are also well-known. Furthermore, Ukrainian folk songs are sometimes given as an example of popular memory of Dazhbog, two of them are especially popular: "Поміж трьома дорогами” (“Among three roads”) and “Ой ти, соловейку” (“Oh, you, the nightingale”), where (sic!) Дажбог (Dazhbog) appears, in the former case, he encounters the fiancé at dawn, going to his own wedding, and in the latter case, Dazhbog forwards the nightingale to open the doors to summer and close them to winter (Топоров 1995: 527-528). Sometimes it is also possible to come across references to other Ukrainian songs mentioning Dazhbog. I think that in this case, the issue is the secondary penetration of mythological character into folklore from literature now without any continuity. Very late record of these rare songs speaks for this, the earliest one dates from 1924, and some songs were written down only in the 1970s (Топоров 1995: 574-575). ${ }^{30}$ The origin of "Dazhbog

\footnotetext{
28 Original: "Перуна и Харса, да Жаба и Мокоша, и Власіи бога скотья и прочая идолы”.

29 Typical Christian name; cf. Byzantine St. Blaise.

${ }^{30}$ Some more songs containing the same refrain “Ой Даждьбоже” (“Oh, Dazhdbog”) were published in 1960s by Kilimnik. I have no confidence in his works; I think (although I would not state that as well, since the detailed reference to this suspiciously abundant data, but for all that remained unnoticed by the earlier ethnographers for some reason, and exceedingly resembling the authors' knowledge of scientific interpretations of the figures used requires special and extensive consideration) that all materials provided here are unlikely to be folk, and
} 
boulder" from Minsk region in Belarus (Belarusian Дажбогаў камень (Dazhbogav kamen); though it was frequently called Saint or just God's one: Cвять (Svyaty), Богау (Bogav)) that ethnographers described as having such a name only in the 1980s is also secondary (Ляўкоў 1992: 64-69): although the very old and traditional cult (the prayers to help by means of offerings; particularly those concerning rainmaking), Dazhbog's name was obviously added artificially later on a literary rather than popular basis. Moreover, in such cases, Dazhbog's name could emerge from a short formula "God grant" (see below) turned to Christian God rather than pagan deity; or in case of Belarusian boulder, from “дождь-бог” (“Dozhd-bog” - "Rain deity").

At the same time, two popular legends of Dabog coming from Serbia and written down in the 1860s are noteworthy. Both are represented in the original and in English (as far as I know, for the first time ${ }^{31}$ ) in the article (Kutarev 2021: 119-122). The first legend tells that Dabog ruled on earth and God on heaven, and God could not diminish Dabog's power that took too many people's souls. However, God was able to determine that his son could defeat Dabog; then, God gave birth to his son, who defeated Dabog and set the souls free. The second legend recounts that God could not create a sufficiently large heaven to cover the earth during the creation of the world. To discover how to improve the situation, he sent the bee to the meeting of demons headed by Dabog, where the latter was talking about in which way the earth could be decreased, and the heaven could be enlarged. However, Dabog then discovered the bee and began to prevent it from returning to God by means of wind and rain. Nevertheless, the bee managed to fly to God and told him everything, following which God improved the world. It seems that Dabog here may be a demonized memory of the supreme pagan deity: he is the head of some "evil spirits" that at the pre-Christian time must be a pagan pantheon. ${ }^{32}$ In spite of demonization, Dabog still appears powerful and wise, which allows him to resist even Christian God.

In modern times, Dazhbog's name has become quite common in culture. The Slavic neopagans call communities and sanctuaries in his honour, and the entrepreneurs name

this is not about the hoax or late penetration of obviously literary element. However, it is possible that refrain only means "God grant", since it occurs here in such a form in similar songs (Килимник 1964: 46-54, 77-84, 99). I would note that the story mentioning Lada, Jar-Jarylo, and Svetovid is provided in the book as a folklore one (Килимник 1964: 123): there is no doubt that such a group does not come from the popular Ukrainian legends. Without immediately attempting finally substantiating or contesting the reliability of this source, I will leave it beyond consideration, nevertheless, without accepting it as a folklore one. To put it mildly, in my opinion, only that information about many "old deities" that Boris Čok has allegedly gathered in Slovenia may be called just "secondary folklore": Dazhbog is also mentioned here along with Sventovit, Triglav, and Perun, see for example (Čok 2015: 109-122 itd.). Without having an opportunity to make a full review here in view of the limited size of this article and on account of the emphasis on somewhat different subject-matter, I have to explain my view in a few words. The reasons for my distrust of Čok are the same: a) overly abundant materials that for some reason remained unnoticed until the $21^{\text {st }}$ century by preceding ethnographers, b) the figures that, on one hand, combine specific elements of religious systems of East and West Slavs that seem to be unique, on the other hand, were unknown in South Slavs before, c) evident signs of the latest and scientific interpretations in "ethnographic" layer of data proper.

31 The first Russian translation was also published by me (Кутарев 2015: 107-108).

${ }^{32}$ At the same time, I omit here the review of literature of the South Slavs, originally approached Dazhbog, mainly Čajkanović and Čausidis (who has published his works in Studia Mythologica Slavica). Their views do not seem convincing to me; (sеe Кутарев, 2016b: 132 и далее). 
their companies after him. Astronomers have named a patera (crater) on Jupiter's satellite Io after Dazhbog (Dazhbog Patera). He is often referred to in works of fiction. Unfortunately, Dazhbog also not infrequently appears in the counterfeits of the Slavic antiquities that we will not consider herein (more about this can be found in Кутарев 2016а; Кутарев 2016b: 133).

\section{SCIENTIFIC INTERPRETATIONS OF DAZHBOG, CHORS AND SVAROG AND THEIR ISSUES}

Although quite stable concepts of Dazhbog's probable functions and relations in the Russian pantheon have been formed, they raise several questions and present not quite resolved issues.

First, the popular interpretation that Dazhbog is a deity of the sun, as many researchers believe, causes difficulties. Indeed, the text of the Primary Chronicle of the Hypatian Codex says that after Svarog's rule: "his son named Sun that is called Dazhbog had reigned", ${ }^{33}$ and he was "the Sun-king, Svarog's son, or Dazhbog” (Kutarev 2021: 114-116). However, the Slavic deities' names have been put in here as the explanations of Greek mythological characters. On the one hand, Dazhbog substitutes for the solar god Helios, whose name the Slavic scribes do not even mention, translating him just as "Sun". However, on the other hand, Dazhbog's characteristic is Svarog's son in both descriptions of the deity. Is it possible that the scribe resorted to a substitution of names because of the identity of relationship: as is the case with Helios and the god of fire Hephaestus, Dazhbog was the son of the deity of fire Svarog rather than because of the identity of functions, meaning that Dazhbog was a deity of the sun as Helios? This assumption, which is no less admissible than the hypothesis of the identity of functions, has also been put forward more than once before by the great specialists in Slavic studies (Мансикка 2005: 93; Ловмянский 2003: 81; Гейштор 2014: 156-157).

Moreover, I would note one more important point that seems to have not been mentioned before in the literature. There is the following fragment in the same Slavic translation of Malala's "Chronographia": "after Dazhbog, Svarog's son, deceased”, Sir reigned in Egypt, followed by Or (Osiris and Hor in the original), followed by Philis, ${ }^{34}$ who asked the oracle saying the following words: "tell me, [not-]lying god, Pirisphon, that is sun" (Истрин 1994: 70). ${ }^{35}$ The function of the deity of the sun is attributed to the male analogue of Persephone here that has neither this male image nor any relation to the sun in Greek myths. It follows that the Slavic translator ${ }^{36}$ (Malala has some fire and truthful sky deity without name rather than Persephone in the original), without particularly understanding,

\footnotetext{
33 Original: “по семъ царствова сынъ его именемъ Солнце егоже наричють. Дажьбогъ”.

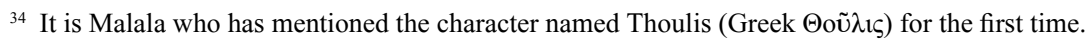

35 Original (II, 2): “по оумрътвіиж Дажьбожи сына Сварагова < ..> цртвова Филисъ”, “повъжь ми, лживыи боже, Пирисфоне, рекше сльньце” (the variant: “неложныи боже”).

${ }^{36}$ The same translator who also added the glosses on Svarog and Dazhbog.
} 
could assign the status of sun deity almost to anyone (see more in Kutarev 2021: 112-113). However that may be, the sources adduce no arguments for the fact that Dazhbog was concerned with the sun, except the comparison with Helios in the translation of Malala. Thus, Dazhbog should not necessarily be the deity of the sun. Let us check this approach considering other problem areas of researching into Dazhbog.

Second, given the aforesaid, the fact that Chors is also usually referred to as the deity of the sun is frankly perplexing. The most significant contemporary research of deity Chors is Vasilyev's work (Васильев 1999: 9-96), in many respects confirming one or another old hypothesis on this issue. The researcher considers the historiography of the issue, rejecting the approaches that are now irrelevant or have become secondary, for example, those about Chors as a deity of the moon (Васильев 1999: 18-24). He also points out the most acknowledged etymology of the name today: it is North Iranian, namely reconstructed Sarmatic and Alanian "*xors/*xūrs 'Sun king"” that after all developed as far back as Avestan "hvarə xšaētəm" having had the same meaning (Васильев 1999: 55-63). Having examined in depth a great number of written sources, linguistic and historical research, Vasilyev is quite convincing when he writes:

"In our opinion, the analysis of the data contained in Old Russian written sources that allow to estimate the East Slavic Chors's nature and functions suggests that in Rus he was considered just as the solar deity, the deity of Sun. And although almost each of the source illustrations provided may be separately contested, taken in their integrity, collectively they form a convincing 'solar vector' for Chors" (Васильев 1999: 54).

Why, if that is so, are there two solar deities in Vladimir's pantheon provided in the Primary Chronicle? Surely, it is possible, but rather strange if we take into account the small size of the "Kiev Olympus". A historiographic stereotype based on writing the Laurentian (the earliest) Codex of the Primary Chronicle has arisen since the time of Bodyansky: “..и Хърса Дажьбога. и Стрибога..”, meaning that in contrast to the Hypatian Codex (quoted above), there is no conjunction "and" between Chors and Dazhbog's names that is between all other deities from the list. On this basis, Chors and Dazhbog could be even considered as one deity having two names, but it seems absurd. Both names are often mentioned independently without any reference, which is illustrated by "The Tale of Igor's Campaign". Beskov has fairly written about the absence of "and" between Chors and Dazhbog in his recent work: "it is a really interesting detail, but one should not overestimate its significance. After all, the names are separated in the Hypatian Codex", and it is also known "apocryphal 'Sermon and Revelation of the Holy Apostles', where Chors and Diy's names are also separated neither with a full stop, nor with the conjunction 'and'. However, nobody has ever suggested identifying this pair of deities with each other! In general, such cases of writing the names of Old Russian deities in sermons against pagans are not unique", for example, there are the following variants in "The Sermon on Idols": “пероуноу хърсоу. и мокоши. и виламъ' (the edition of Novgorod St. Sophia Library), 'пероуноу. хорсоу мокоши. 
Виламъ' 37 (Chudovo edition)", among others (Бесков 2008: 111). It seems that the omission of "and" between Chors and Dazhbog's names in the Laurentian Codex may be considered accidental, meaningless.

The mythological attempts to explain the presence of two solar deities in the list of only six characters are also unsuccessful. Rybakov's opinion is often referred to here: "White Light (Universe) refers to the sun as Dazhbog (the deity of light and sun) refers to Chors (the deity of only one heavenly body), as Apollo to Helios" (Рыбаков 1981: 433). However, the complicated interrelation between Apollo and Helios is not a common concept for European paganism, "in Greek mythology such overlapping and functions partition are the result of long-term development and rise of Apollo: he was not a deity of sun at first" (Клейн 2004: 243). It is well known that

"[...] early in the development of ancient Greek religion, Apollo was a cruel and gloomy deity, and one of his most ancient functions was the function of destroyer. And the solar nature began to be attributed to this deity quite late: the texts, where Apollo and Helios-Sun had been equated with each other, had appeared only since 5th century В.С." (Васильев 1999: 57-58).

The views, having travelled a unique and long path in Greece, cannot be applied to the Slavic material, where thereby there are too many solar deities. However, the approach under which Dazhbog is not a solar deity, can solve this issue. Only Chors is a solar deity of the East Slavs can do so, as Vasilyev also shows. At the same time, when the researcher writes: "but the solar nature of Dazhbog is indisputable" (Васильев 1999: 27), he nowhere even attempts to substantiate this opinion, let alone even any consideration of it; the thesis is given a priori as an axiom. Unfortunately, it is commonplace in the literature despite all the specified instances of it not fitting.

Third, Dazhbog is not infrequently identified with Svarozhich; in many modern Slavic languages, including Russian, a patronymic is formed from a name by means of a suffix -ич (-ich) that is an obligatory constituent of a personal name of Russians, Ukrainians, and Belarusians (e.g., Lev Nikolayevich Tolstoy has a patronymic Nikolayevich as Nikolay's son, etc.). There also was such a word formation in Old Russian. The identification of Fire-Svarozhich from the Sermons against Pagans with Dazhbog could be concluded from it, or, more frequently, that they were brothers from their father Svarog, for example (Гейштор 2014: 160). However, it was noted above that word Svarozhets generally denoted the Fire Deity, where the suffix -ets gives a diminutive meaning: "little Svarog" (Brückner 1918: 148-149). In essence, the suffix -ich could also be used in such a meaning at all times (best of all, it has been preserved in modern Russian in the words of feminine gender having two suffixes, such as лисичка [lisichka] ("little fox" from лиса [lisa] "fox"), водичка [vodichka] (“little water" from вода [voda] "water"), etc.).

\footnotetext{
37 In other words, if the absence of conjunction "and" between the names allegedly allows to identify or draw together the characters, Perun and Chors "can" merge, and in some cases even female deities Mokosh and Vilas "can" merge with them as well.
} 
Thus, although Dazhbog was Svarog's son, he is no Svarozhich or Svarozhets. Neither in the Russian mythology nor in the paganism of the Baltic Slavs (the native speakers of West group of Slavic languages), where the deity Zuarasiz was mentioned early in the $11^{\text {th }}$ century by Bruno of Querfurt (in a letter to the German king St Henry II); or the deity Zuarasici was mentioned in the 1010s by Thietmar of Merseburg ("Chronicon", VI, 23 $)^{38}$ if the correlation of these gods with the East Slavic Fire-Svarozhets is possible.

Both "little" Svarozhets and "big" Svarog, even if there was any difference between them, except origin (East and South Slavic, respectively), are the deity of fire as clearly follows from the sources; although the former is more like a deified flame proper, and the latter rather appears in the form of a blacksmith. Let me particularly note one more historiographic stereotype: a popular theory of cognation between the Sanskrit word "svarga" ("sky") and Svarog's name. This alleged proximity is almost impossible from the linguistic point of view (Мансикка 2005: 297; Фасмер 1986: 569-570). Another weighty theory derives Svarog's name from the Slavic notion "свара" [svara], i.e., quarrel, discord, relating it to the function of chastising deity, for it is Svarog that had introduced punishment for betrayals (Фасмер 1986: 569; Гейштор 2014: 157). However, the etymology deriving the word from the Slavic root "вap" [var], meaning "boiling", "broth", should be considered preferable, (Гальковский 2013: 16), including those word with a prefix “s-" (сf. “сварка" [svarka] (“welding”), “сварить” [svarit] (“to boil”), and similar.

\section{DAZHBOG AS THE SLAVIC SKY FATHER}

Thus, Dazhbog is not a solar deity, since the Chors was that deity; and Dazhbog has no function of the fiery deity, although Dazhbog is Fire Deity's son in the Slavic mythology. In that case, whom could Dazhbog be considered in accordance with the sources? Let me note his most obvious function in the Old Russian texts, namely the role of an ancestor for "Dazhbog's grandchildren" in "The Tale of Igor's Campaign". Regardless of whoever these grandchildren may be, either the Russians in general (which seems the most probable to me) or only a princely family, in any event, Dazhbog acts as Parent God, Father God.

Indo-European mythology knows well that image; the name of this god reconstructed as *Dyeus-Phater. The deity "Dyaus Pitar 'Sky Father"” (in Sanskrit Dyauṣpitṛ and similar variants) has been mentioned more than once in Indian Vedas, including the most ancient one, "Rigveda" $\left(15^{\text {th }}-10^{\text {th }}\right.$ centuries B.C.). Although, according to Erman, this deity "goes back to Common-Indo-European period", nevertheless, "as far back as 'Rigveda', the worship of Dyaus was reflected at the extinction stage, later Dyaus was mentioned rarely" (Индуизм Словарь 1996: 190, 375); and thunderer and conqueror Indra appears as the chief deity in "Rigveda". In Greek myths, Zeus acts as Sky Father; in essence, his name with the epithet "Father": Greek Zev́s $\pi \alpha \tau \dot{\varepsilon} \rho$ [Zeus pater] has the same stem as

${ }^{38}$ Later, this deity turned into Riedegost (and similar variants of spelling) first in Adam of Bremen's chronicle (II, 21) (Адам Бременский 2011: 41), and then in chronicle of Helmold of Bosau (XI-XII centuries); with Thietmar having called in this way only the town, where deity Zuarasici was worshipped (Ловмянский 2003: 139-152). 
Dyaus Pitar and the Roman name of Sky Father Jupiter (Latin *I(o)u-pater). In many Indo-European languages, the word "deity" (for example, Sanskrit "deva", Greek " $\theta \varepsilon$ ć $\varsigma$ " [theos], Latin "deus", etc. ${ }^{39}$ ) also derives from Proto-Indo-European *dyeu-, originally meaning "sky". Likewise, the word "father" is also resembling in various Indo-European languages (Slavic “отец” [otets], “батя” [batya]).

The Scandinavian deity Týr, well-known for Icelandic myths, develops from a hypothesized Proto-Germanic deity named *Tiwaz; and the denotation of "Tuesday" derives from the English form of this deity's name. In the Balts' folklore, Dievas (Lithuanian Dievas, Latvian Dievs; this word also means the notion "God" proper) is a supreme deity, although the thunderer Perkūnas (Lithuanian Perkūnas, Latvian Pērkons), whose name is similar to the Slavic Perun, ${ }^{40}$ sometimes is opposed to him in that role. It is interesting that in a number of cases Sky Father is "pushed" to the sidelines of the mythology (as Scandinavian Týr having lost his hand, or Indian Dyaus Pitar, whose certain conflict with Indra is visible), and sometimes the Sky Father and the Thunderer are the same character (Zeus, Jupiter). It seems that during some period of time similar (or even identical) images of Sky Father and Thunderer began to separate in Indo-European communities, with the Thunderer (if he separated in mythology) beginning to play a more significant role in military aristocracy within the period of settling apart the Indo-Europeans, and pushing aside formerly supreme Sky Father. In other cases, no separation has taken place, and then only the function of Sky Father was pushed to the sidelines as compared with the military and powerful one (Кутарев 2016b: 134-138).

The Slavic thunderer Perun in no way proves to be a Father/Ancestor in the sources. At the same time, the images of Sky Father and Thunderer are separated in the Balts, the closest to the Slavs, as well as other North Indo-Europeans. In this way, "it was worth supposing the Slavs' thunderer's latent struggle with the deity of the sky for superiority in the pantheon, which was between Zeus and Cronos ${ }^{41}$ in the Greeks, and between Indra (and, perhaps, even Parjanya substituted by him) and Dyaus in the Indo-Aryans" (Клейн 2004: 139); and between Perkūnas and Dievas in the Balts. Then why can we not see the Slavic parallel to Dievas, which is suggesting itself? Where is the very Sky Father, who has become the Slavs' successor of Proto-Indo-European *Dyeus-Phater?

Dazhbog is fit to be the Sky Father upon a great number of criteria at once, while no other Slavic deities meet all of them. Firstly, Dazhbog is an ancestor (i.e., Father Deity), which clearly follows from the image of "Dazhbog's grandchildren" in "The Tale of Igor's Campaign”. Secondly, he plays a significant part in mythology without being, nevertheless, the supreme deity.

"As a deity of thunderstorm and thunder, Perun (Indo-European *Per(kw)uno-s), whose 'sacral roots' go back to the time of Indo-European commonality,

\footnotetext{
39 The word "диво" [divo] ("marvel, miracle") from same stem has been preserved among the Slavs.

${ }^{40}$ It is believed that the Baltic mythology, as well as the Baltic languages are the closest to the Slavic according to the origin.

${ }^{41}$ Klejn is likely to have made a misspelling here (corrected by me): struggle, which "was between Zeus and Chronos".
} 
was related to the military sphere and considered to be a patron of warriors and their leader as far back as that time. With 'the beginning of the heroic era of settling apart the Indo-Europeans, evidently, since the end of III millennium B.C.', the role of military function had been growing in the social structure of the Indo-European tribes, which put the deity of thunderstorm in the forefront in their pantheon. It is quite natural that within the period of forming the Old Russian state and a lot of military activities of the first Kiev princes, Perun turned into the patron deity of them and the prince's armed force" (Васильев 1999: 213).

However, Dazhbog has remained among the most important worshipped characters of East and South Slavs (perhaps, the West as well? For the deities' names of Poland and Czech until the $15^{\text {th }}$ century are unknown) together with solar deity Chors and some other deities. Putting Perun in the forefront was likely taking place simultaneously with pushing the very Dazhbog to the sidelines, whose role of an ancestor, however, was not forgotten even 200 years after the Christianization of Rus, when "The Tale of Igor's Campaign" was being created.

Of no small importance, linguistic research may also be involved here. Only Stribog's name was attempted to be explained as an evolution of Proto-Indo-European name *Dyeus-Phater among the significant deities of the Slavs, representing its etymology as "father deity" (Рыбаков 1981: 432). However, as Toporov notes, "evidently, it is necessary now to reject (or at least seriously reconsider) deriving of the first element of this name from the word denoting father (Indo-European * patri>Slavic stri) as it was done by many researchers, and interpret stri- as an imperative from verb stbrti "stretch", "spread" as R.O. Jakobson suggested in his works as well” (Топоров 1995: 529; Фасмер 1986: 777; Клейн 2004: 244). The mysterious "Div" (demon or bird) being referred to only in "The Tale of Igor's Campaign", at one moment shouting from a tree, at another being thrown down to the land, evidently does not fit for the Sky Father as to the status (СПИ 1800: 9, 25; СПИ 1985: 37, 40). The name of "Diy or Dyw, the deity of rain and sky, i.e. Zeus" is of literary and undoubtedly Greek origin, also known for some Sermons against Pagans. "However, in Russian, this word was used in the sense of pagan deity in general. Our ancestors did not worship Diy. Diy has got into our Olympus due to the ancient scribes' knowledge of Byzantine historical literature"42 (Гальковский 2013: 11-12). The Slavs have no other male deities similar to the name *Dyeus-Phater.

What is the etymology of Dazhbog's name? Here we come across another historiographic "axiom" that seems to be better to be considered again. Dubensky's theory proposed as far back as the first half of $19^{\text {th }}$ century appears to be established: "he explained the first half of the name ('Dazhd-') as an imperative from verb 'дать' [dat] ('to give'): Dazhdbog: 'Дай Бог’ [Dai Bog] ('God grant'). On this basis, the name Dazhdbog is defined

\footnotetext{
${ }^{42}$ For example, the very Slavic translation of Malala's "Chronographia" says (I, $20=$ I, 13): "Зеоусъ єго же

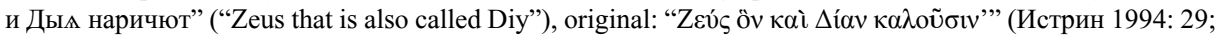
IMC 2000: 14).
} 
as 'giving god'43 [...]; 'deus donator'” (Соколова 1995: 80). However, as stated, the form of the name "Dazhdbog" (containing two letters " $d$ ") is represented in the sources in an absolute minority: only two records of the Hypatian Codex mention it (and even then, they do not always follow this spelling), and none of the editions of the Laurentian Codex has it. It never appears in the Sermons against Pagans, and as stated, there is one spelling "Dazhd-Bozha" and another "Dazh-Bozha" (both in genitive) in "The Tale of Igor's Campaign". Istrin points out the exclusive form “Дажьбогъ” in the reconstructed Slavic translation of Malala (Истрин 1994: 69-70).

This overwhelming prevalence of form "Dazhbog" containing no second letter " $\mathrm{d}$ " requires a philological explanation, and it was offered. Having considered many examples, the linguists have established that the palatalization with " $\mathrm{j}$ " occurred in different ways in various groups of Slavic languages. Say, proto-Slavic word *mĕdjā 'border' has acquired the form "мєжда" ("mezhda") in the South Slavs (in Old Slavonic); Old Russian "мєжа" ("mеzha") in the East Slavs, but, for example, Polish "miedza" or Czech "meze" in the West Slavs. Similarly, if Dazhbog's name derives from the imperative of a word "dat" in various Slavic languages, the Old Slavonic (Bulgarian and Macedonian) form would be Dazhdbog (from "dazhd"), the East Slavic form Dazhbog (from "dazh"), and reconstructed Lechitic one * Dadzьbogъ (Old Polish Dadzibog), whereas Old Czech would be ${ }^{*}$ Dazbbogъ. ${ }^{44}$ Since the East Slavs adopted written language and literature in Old Slavonic from the South Slavs, the Bulgarian and Macedonian forms have long prevailed in the Old Russian book-learning, being the standard there despite other forms of the Old Russian proper.

However, it seems that another explanation of the prevalence of the form "Dazhbog" in the sources is more probable. Many researchers "considered the form 'Dazh-Bog' to be original, and the first part of the name ('Dazh-') to be a possessive adjective from extinct Slavic word 'дагъ' [dag] (cf. Gothic dags, German Tag, etc.), i.e., day, light (A.N. Afanasyev, I.I. Sreznevsky, F.I. Buslaev, A.S. Famintsyn, L.P. Yakubinsky, B.A. Rybakov ${ }^{45}$ ).

\footnotetext{
${ }^{43}$ At Jakobson's suggestion, the meaning "wealth, good" was also looked for in the part "-bog" of Dazhbog and Stribog's names, but this context (even if it was derived from the acknowledged Iranian etymology of a word) would be strange to be seen only in two names, without applying to all other occurrences of quite independent word "бог" [bog] ("god") (Соколова 1995: 80).

${ }^{44}$ I thank Zenkin for tips on linguistics.

${ }^{45}$ Klejn may be also added to this list, who writes about the extreme uncommonness of the formation of the word from imperative of a verb: in his opinion, it is more logical to regard "it as a later comprehension (according to consonance). The assumption [...] that Dazh- is a natural Russian palatalization of ancient Indo-European word "dag"" that is concerned with the notion of day and heat "is likely to be more correct"; it is also easier to get to the Serbian form Dabog through this assumption (Клейн 2004: 242). Kareev also wrote: "Dazh means ablaze, burning, from root dag ('to burn'); Lithuanian degu ('I am burning'); German Tag; Carantanian дъж-ница ('dawn'), etc.” (Кареев 2011: 33). Tvorogov also has not called Dazhdbog (though preferring this spelling) solar (in contrast to Chors, "the deity of sun and light heavenly body") in his latest works, pointing out only his function of "the deity of light and giver of good" (БЛДР 2000: 501). Maintaining the same etymology, nevertheless, Hilferding derived the deity's solar function, he wrote: "as to another name of the deity of Sun, Dazhbog, it also seems to contain a notion of burning, fire: we have no doubt in correctness of derivation of this name that was first proposed by honourable Mikutskiy as we know, it was derived from the ancient root daz [dag] - 'burn' (Sanskrit dah, Lithuanian degu, degti 'I burn', 'to burn', Slavic dëzomb [dyogot' 'tar'], and,

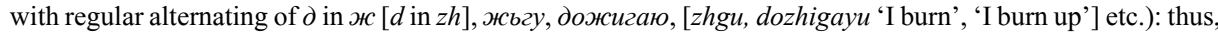
Dazhbog means a burning deity” (Гильфердинг 2013: 259-260 прим. 699).
} 
Sreznevsky considered the extant word having the same root 'дъжница' [dzhnica] (dawn) in the Carantanian language ${ }^{46}$ to be the evidence of the existence of the word 'dag' in Slavic. Deriving 'Dazh' from 'dag' (interchange of 'g' and 'zh'), Yakubinsky considered the form Dazhdbog wrong” (Соколова 1995: 80). Thus, it seems that this version of etymology has been undeservedly passed over. Although, as to the extent of my knowledge, none of the researchers proved its incorrectness and impossibility, or at least a little convincingness; and it constantly occurs in individual works of both the second half of the $20^{\text {th }}$ century (Соколова 1995), and the $21^{\text {st }}$ century (Клейн 2004), it is not noticed and "forgotten" to be mentioned, since another view "came into vogue" (despite shortcomings). Meanwhile, this approach perfectly combines with all those research studies that were carried out above and is perfectly fit for Dazhbog: the Sky Father concerned with day and light. It is also easy to explain the infrequent appearance of the form containing the second letter " $\mathrm{d}$ ":

"Dazhdbog: one geographical name in Mosalsky uyezd ${ }^{47}$ also sounds like this; this form can strengthen an opinion of those, who [...] derive this name from the imperative of verb damu. However, I look at things in a different way: when people forget the real meaning of a word, they often resort to a small change in pronunciation to adapt the word to the sounds of another, more familiar word, by means of that change" (Кареев 2011: 32).

Therefore, the form "Dazhdbog" containing second letter " $d$ " is secondary (cр. Ляўкоў 1992: 67-68), which is clearly shown to us by the sources.

Thus, we can talk about the probability of etymology of the name Dazhbog as the Slavic evolution of Indo-European *Dyeus-Phater ${ }^{48}$ and the corresponding mythological change. The stem Dazh- correlates with *Dyeus-, and "-bog" could substitute for "-father" (*-Phater), however, having been preserved as a function in mythology. The etymological chain appears: Dazhbog's name derives from Proto-Slavic *dagb (day); while the very word “день" [den] undoubtedly goes back to Proto-Indo-European *dyeu-. The outline of my reconstruction is as follows:

Proto-Indo-European *Dyeus $>$ Proto-Slavic *dagz ("day") > Proto-Slavic Dazh-

As a result, in my opinion, Dazhbog is a Slavic version of the evolution of the Indo-European image of Sky Father (*Dyeus-Phater) just as Dievas functions as that in the Balts. Both Dazhbog's features of ancestor proper ("Dazhbog's grandchildren" in the "The Tale of Igor's Campaign") and etymology speak for this. At the same time, Dazhbog

\footnotetext{
46 To put it more precisely, this word is dialecticism of Slovene.

47 In the west of Kaluga Region in Russia. However, I have not found such a name on a modern map.

${ }^{48}$ In 2015, in Moscow I talked about it with a reknowned specialist in Indo-European studies Vyacheslav V. Ivanov, who said that such a reconstruction was not without difficulties, but was possible to be considered.
} 
has no particular "rivalry" in this domain, for he is the only deity that combines both the possibilities of etymological development from *Dyeus-Phater and functional similarity with him. I see no need to finally reject his relation to solar and fiery functions as well; they could be well related to the archetype of Sky Father one way or another as in other Indo-European mythologies. However, in my opinion, surely, it was not prevailing, for when approached closely, it is clear that Chors acted as the chief solar deity, and Svarog/ Svarozhets as the fiery one. While the warrior Thunderer Perun was the closest to the militarized part of society and princes, evidently the cult of Dazhbog, whose function of "father" concerned not only folk and people but also the world, harvest and plenty in general, was more significant for common people being drawn to agriculture; in this regard, he truly was the giver and distributor of good. Surely, Perun was also responsible for harvest to some extent, being concerned with rain, but it seems that it is difficult to name at least one deity of the Slavic pantheon that would not be somehow concerned with fertility. However, Dazhbog's emphasis thereon was particular and specific.

In this sense, Scandinavian paganism appears to be the closest for comparison, where Thor and Odin are attached to warriors, leaders and elements, and Freyr to fertility (cf. Adam of Bremen (IV, 26)): in Sweden, there was a pagan temple of Uppsala, where "there are statues of three deities worshipped by people. [...] Their powers are distributed in the following way: 'Thor, the Swedes say, reigns in the air, controls thunder and rivers, winds and rains, fair weather and harvests. The second one is Wodan, which means 'frenzy', who wages wars, gives people courage in battles against the enemies. The third one is Fricco that grants peace and pleasures to the mortal people"' (Адам Бременский 2011: 108) ${ }^{49}$ In this case, Perun (and Veles to some extent?) can be compared with Thor and Odin, and analogy may be drawn between Freyr and the very Dazhbog. However, "it is not impossible that the pagan East Slavs worshipped Christian God in Dazhbog" as the Balts worshipped him in Dievas (Мансикка 2005: 295; Ляўкоў 1992: 67).

It is not unusual that, being the Sky Father, Dazhbog appears to be Svarog's son. Fire is a chthonic, ancient, and creating element, with which the archetype of creating demiurge blacksmith (mythological insight of the Big Bang?) was coordinated. For example, Olympian deities headed by Zeus represent the third generation, struggling with the Titans preceding them; the deities of the Irish Celts - Folk of the goddess Danu - appeared later also struggled for power over Ireland with the Formorian giants in the epic Battle of Magh Tuireadh. Similarly, the Germans had Ymir and other giants that existed until the deities, who appeared later and fought against their predecessors. In Indians' Vedas, this conception is also well-known, there are "two kinds of creatures: deities and asuras [giants - O.K.]. And the deities were younger, and asuras older. They have fought against each other for these worlds"50 (Упанишады 2003: 72). Although Dazhbog could be the

\footnotetext{
${ }^{49}$ English translation is made according to the Russian edition. Original (Latin): "statuas trium deorum veneratur populous [...]. Quorum significationes eiusmodi sunt: 'Thor', inquiunt, 'presidet in aere, qui tonitrus et fulmina, ventos ymbresque, serena et fruges gubernat. Alter Wodan, id est furor, bella gerit hominique ministrat virtutem contra inimicos. Tercius est Fricco, pacem voluptatemque largiens mortalibus"”.

${ }^{50}$ Brihadaranyaka Upanishad, I, 3.1. Original (Sanskrit): "tataḥ kānīyasā eva devāh, jyāyasā asurāh, ta eșu lokeșv aspardhanta".
} 
winner in the struggle for the supremacy in the world in the Slavs' myths having not reached us, ${ }^{51}$ later he was pushed to the sidelines by the militarized part of society and its cult of Perun: it is that condition in which these two supreme deities have been fixed by the Old Russian sources. ${ }^{52}$

\section{REFERENCES ${ }^{53}$}

Brückner, A., 1918: Mitologja stowiańska. Krakow: NAU.

Čok, B., 2015: Kamnoseško izročilo o znamenjih na portalih in kolonah po Krasu. Nesnovna krajina Krasa (ur. Katja Hrobat Virloget in Petra Kavrečič). Koper: Založba Univerze na Primorskem. Pp. 99-134.

IMC, 2000: Ioannis Malalae Chronographia. Rec. I. Thurn. Berolini: Walter de Gruyter.

Kutarev, O. V., 2019: Description of Rod and Rožanicy in Slavic mythology: B. A. Rybakov and his predecessors' interpretations. New researches on the religion and mythology of the Pagan Slavs (ed. by Patrice Lajoye. Paris: Lingva). Pp. 33-45. PDF: https://vk.com/ doc-120497_509056662

Kutarev, O. V., 2021: The analysis of the sources on Slavic deity Dazhbog: Hypatian Codex; Serbian legends of Dabog. Сборник научных статей по итогам работь Международного научного форума «Наука и инновации - современные концепции» (г. Москва, 26 февраля 2021 г.; отв. ред. Д.Р. Хисматуллин. - М.: Инфинити). Pp. 104-125. PDF: https:// vk.com/doc-120497_591698209

Słupecki, L. P., Zaroff, R., 1999: William of Malmesbury on Pagan Slavic Oracles: New Sources for Slavic Paganism and its two Interpretations. Studia Mythologica Slavica 2. Pp. 9-20.

Адам Бременский, 2011: Деяния архиепископов Гамбургской церкви. Славянские хроники. Москва: Русская Панорама. С. 7-150. [Adam Bremenskij 2011: Deyaniya arhiepiskopov Gamburgskoj cerkvi. Moskva: Russkaya Panorama. Pp. 7-150.]

Бесков, А. А., 2008: Анализ мифологической составляющей восточнославянского язычества: Дис. ... канд. филос. наук. Нижний Новгород. [Beskov, А. А., 2008: Analiz mifologicheskoj sostavlyayushchej vostochnoslavyanskogo yazychestva: Dis. ... kand. filos. nauk. Nizhnij Novgorod.]

БЛДР, 2000: Повесть временных лет (по Ипатьевской редакции). Библиотека литературы Древней Руси. Т. 1. Санкт-Петербург: Наука. С. 62-315. [Povest'vremennyh let (ро Ipatyevskoj redakcii). Biblioteka literatury Drevnej Rusi. T. 1. Sankt-Peterburg: Nauka. Pp. 62-315.]

Васильев, М. А., 1999: Язычество восточных славян накануне крещения Руси: Религиозномифологическое взаимодействие с иранским миром. Языческая реформа князя Владимира. Москва: Индрик. [Vasilyev, М. А., 1999: Yazychestvo vostochnyh slavyan

\footnotetext{
${ }^{51}$ Dazhbog is likely to be logically seen as Mother Earth's husband that way that is poorly personified in the folklore (as Mat Zemlya) and the sources (for example, "zemlya-mat" (Mother Earth) ("земл м мати") was referred to in the Primary Chronicle of 988 as the element worshipped by the Christians (БЛДР 2000: 161; Лавр. стб. 114-115; Ипат. стб. 100)), but it is still treated with remarkable respect by the Slavs.

${ }^{52}$ And, perhaps, Procopius of Caesarea as well, who wrote in 6th century about the fact that in the paganism of the Slavs "the creator of thunderstorm" dominates (Гейштор 2014: 98-99).

${ }_{53}$ All dates for internet resources are given on 15. 04. 2021.
} 
nakanune kreshcheniya Rusi: Religiozno-mifologicheskoe vzaimodejstvie s iranskim mirom. Yazycheskaya reforma knyazya Vladimira. Moskva: Indrik.]

Гальковский, Н. М., 2013: Борьба христианства с остатками язычества в Древней Руси. Москва: Академический проект [both volumes in one book; the second volume is a reprint of 1913 (p. 263-572), with page numbering x+264 (p. 300 in 2013=p. 36 in 1913)] [Galkovskij, N. M., 2013: Borba hristianstva s ostatkami yazychestva v Drevnej Rusi. Moskva: Akademicheskij proekt.]

Гейштор, А., 2014: Мифология славян. Москва: Весь мир. [Gieysztor, А. 2014: Mifologiya slavyan. Moskva: Ves' mir.]

Гильфердинг, А. Ф., 2013: История балтийских славян. М.: Русская Панорама. [Hilferding, A.F. 2013: Istoriya baltijskih slavyan. M.: Russkaya Panorama.]

Зализняк, А. А., 2008: «Слово о полку Игореве»: взгляд лингвиста. Москва: Рукописные памятники Древней Руси. [Zaliznyak, A.A. 2008: «Slovo o polku Igoreve»: vzglyad lingvista. Moskva: Rukopisnye pamyatniki Drevnej Rusi.]

Индуизм Словарь, 1996: Индуизм. Джайнизм. Сикхизм: Словарь (под общ. ред. М. Ф. Альбедиль и М. Ф. Дубянского). Москва: Республика. [Induizm. Dzhajnizm. Sikkhizm: Slovar' (pod red. M. F. Albedil i M. F. Dubyanskogo). Moskva: Respublika.]

Ипат., 1908: Ипатьевская летопись: Полное собрание русских летописей. Т. 2. Издание второе. Санкт-Петербург. [Ipatyevskaya letopis': Polnoe sobranie russkih letopisej. T. 2. Izdanie vtoroe. Sankt-Peterburg.]

Истрин, В. М., 1994: Хроника Иоанна Малаль в славянском переводе. Москва. PDF: https:// vk.com/doc-120497 589964358 [Istrin, V. M., 1994: Hronika Ioanna Malaly v slavyanskom perevode. Moskva.]

Кареев, Н. И., 2011: Главные антропоморфические боги славянского язычества. Исследования в области древней мифологии. Москва, Либроком. [Kareev, N. I. 2011: Glavnye antropomorficheskie bogi slavyanskogo yazychestva. Issledovaniya v oblasti drevnej mifologii. Moskva, Librokom.]

Килимник, С. I., 1964: Украӥнський рік у народних звичаях в історичному освітленні. Т. 1 (Зимовий цикль). Вінніпег. [Kilimnik, S.I. 1964: Ukrainskij rik u narodnih zvichayah v istorichnomu osvitlenni. T. 1 (Zimovij cikl). Winnipeg.]

Кирпичников, А. И., 1885: Что мы знаем достоверного о личных божествах славян. Журнал Министерства народного просвещения. Сентябрь 1885. № CCXLI (241). СанктПетербург. С. 47-65 (вторая пагинация). [Kirpichnikov, A.I., 1885: Chto my znaem dostovernogo o lichnyh bozhestvah slavyan. Zhurnal Ministerstva narodnogo prosveshcheniya. Sentyabr 1885. № CCXLI (241). Sankt-Peterburg. Pp. 47-65 (vtoraya paginaciya).]

Клейн, Л. С., 2004: Воскрешение Перуна. К реконструкции восточнославянского язычества. Санкт-Петербург: Евразия. [Klejn, L. S., 2004: Voskreshenie Peruna. K rekonstrukcii vostochnoslavyanskogo yazychestva. Sankt-Peterburg: Evraziya.]

Кутарев, О. В., 2015: Древнерусский Дажьбог, сербский Дабог и греческий сын Гефеста Гелиос. Acta Eruditorum. 2015. Вып. 19. Санкт-Петербург: Издательство РХГА. С. 101-109. LJ: https://dajbojic.livejournal.com/5180.html [Kutarev, O. V. 2015: Drevnerusskij Dazhbog, serbskij Dabog i grecheskij syn Gefesta Gelios. Acta Eruditorum. 2015. Vyp. 19. Sankt-Peterburg: Izdatelstvo RHGA. S. 101-109.]

Кутарев, О. В., 2016а: История мистификаций и домыслов в области славянского пантеона (до середины XIX в.). Язычество в современной России: опыт междисциилинарного исследования (под ред. Р. В. Шиженского). Нижний Новгород: Мининский университет. C. 133-160. PDF: https://vk.com/doc-120497_442906131 [Kutarev, O. V., 2016a: Istoriya 
mistifikacij i domyslov v oblasti slavyanskogo panteona (do serediny XIX v.). Yazychestvo v sovremennoj Rossii: opyt mezhdisciplinarnogo issledovaniya (pod red. R.V. Shizhenskogo). Nizhnij Novgorod: Mininskij universitet. Pp. 133-160.]

Кутарев, О. В., 2016b: Славянский Дажьбог как развитие индоевропейского Бога Сияющего Неба (Дьеус-Патер). Философия и культура №1. С. 126-141. DOI: 10.7256/19992793.2016.1.17386 PDF: https://vk.com/doc-120497_437685885 [Kutarev, O. V. 2016b: Slavyanskij Dazh'bog kak razvitie indoevropejskogo Boga Siyayushchego Neba (D'eus-Pater). Filosofiya i kul 'tura №1. Pp. 126-141.]

Кутарев, О. В., 2018: О причинах (не)упоминаний славянского язычества в западноевропейских источниках VI-XIII вв. SoсіоTime. Социальное время. №3 (15). C. 113-122. PDF: https:// vk.com/doc-120497_486090289 [Kutarev, O. V., 2018: O prichinah (ne)upominanij slavyanskogo yazychestva v zapadnoevropejskih istochnikah VI-XIII vv. SocioTime / Social'noe vremya. №3 (15). S. 113-122.]

Лавр., 1926: Лаврентьевская летопись. Полное собрание русских летописей. Т. 1. Издание второе. Ленинград. [Lavrentyevskaya letopis'. Polnoe sobranie russkih letopisej. Т. 1. Izdanie vtoroe. Leningrad.]

Ловмянский, Г., 2003: Религия славян и её упадок. Санкт-Петербург: Академический проект. [Łowmiański, H., 2003: Religiya slavyan i eyo upadok. Sankt-Peterburg: Akademicheskij proekt.]

Ляўкоў, Э. А., 1992: Маўклівыя сведкі мінуўшчыны. Мінск. [Levkov, Е. А., 1992: Mavklivyya svedki minuvshchyny. Minsk.]

Мансикка, В. Й., 2005: Религия восточных славян. Москва: ИМЛИ РАН. [Mansikka, V. J., 2005: Religiya vostochnyh slavyan. Moskva: IMLI RAN.]

Письменные памятники, 2003: Письменные памятники истории Древней Руси (сост. Я. Н. Щапов). Санкт-Петербург: Блиц. [Pis'mennye pamyatniki istorii Drevnej Rusi (sost. Ya. N. Shchapov). Sankt-Peterburg: Blic.]

Рыбаков, Б. А., 1981: Язычество древних славян. Москва: Наука. [Rybakov, В. А., 1981: Yazychestvo drevnih slavyan. Moskva: Nauka.]

Соколова, Л. В., 1995: Дажьбог (Даждьбог). Энииклопедия «Слова о полку Игореве»: $B 5$ m. Санкт-Петербург: Дмитрий Буланин. Т. 2. С. 79-82. [Sokolova, L. V., 1995: Dazhbog (Dazhdbog). Enciklopediya «Slova o polku Igoreve»: $V 5$ t. Sankt-Peterburg: Dmitrij Bulanin. T. 2. S. 79-82.]

СПИ, 1800: Ироическая пъснь о походъ на половцовъ удъльнаго князя Новагорода-Съверскаго Игоря Святославича. Москва: Въ Сенатской Типографіи. Первое издание «Слова о полку Игореве»: https://dajbojic.livejournal.com/4207.html [Iroicheskaya p bsn'o pohod b na polovcov ud l'nago knyazya Novagoroda-Stverskago Igorya Svyatoslavicha. Moskva: V Senatskoj Tipografii.]

СПИ, 1985: Слово о полку Игореве. Воинские повести Древней Руси. Ленинград: Лениздат. С. 36-44. https://dajbojic.livejournal.com/4549.html [Slovo o polku Igoreve. Voinskie povesti Drevnej Rusi. Leningrad: Lenizdat. Pp. 36-44.]

СРНГ, 2002: Словарь русских народных говоров. Вып. 36. Санкт-Петербург: Наука. [Slovar' russkih narodnyh govorov. Vyp. 36. Sankt-Peterburg: Nauka.]

Степенная книга 1775: Книга степенная Царскаго родословія содержащая исторію Россійскую съ начала оныя до времёнъ государя Царя и Великого князя Іоанна Васильевича, сочинённая трудами Преосвященных Митрополитов Кипріана и Макарія. Ч. 1. Москва: Императорский университет. [Kniga stepennaya Carskago rodosloviya soderzhashchaya istoriyu Rossijskuyu s nachala onyya do vremyon gosudarya Carya $i$ Velikogo 
knyazya Ioanna Vasil'evicha, sochinyonnaya trudami Preosvyashchennyh Mitropolitov Kipriana i Makariya. CH. 1. Moskva: Imperatorskij universitet.]

Творогов, О. В., 1983: Материаль к истории русских хронографов. 2. Софийский хронограф $u$ «Хроника Иоанна Малалы» (Труды Отдела древнерусской литературы.) Ленинград: Наука. T. 37. С. 188-192. [Tvorogov, O. V., 1983: Materialy k istorii russkih hronografov. 2. Sofijskij hronograf $i$ «Hronika Ioanna Malaly» (Trudy Otdela drevnerusskoj literatury). Leningrad: Nauka. T. 37. Pp. 188-192.]

Творогов, О. В., 1987: Хроника Иоанна Малалы. Словарь книжников и книжности Древней Руси. Ленинград: Наука. Вып. 1. С. 471-474. [Tvorogov, O. V., 1987: Hronika Ioanna Malaly. Slovar'knizhnikov i knizhnosti Drevnej Rusi. Leningrad: Nauka. Vyp. 1. Pp. 471-474.]

Топоров, В. Н., 1995: Об иранском элементе в русской духовной культуре. Святость и святые в русской духовной культуре. Москва: Гнозис. Т. 1. [Toporov, V. N., 1995: Ob iranskom elemente v russkoj duhovnoj kul'ture. Svyatost'i svyatye v russkoj duhovnoj kul'ture. Moskva: Gnozis. T. 1.]

Упанишады, 2003. М.: Восточная литература. [Upanishady, 2003. M.: Vostochnaya literatura.]

Фасмер, М., 1986: Фасмер М. Этимологический словарь русского языка, Том 3. Москва: Прогресс. [Fasmer, M., 1986: Fasmer M. Etimologicheskij slovar'russkogo yazyka, Tom 3. Moskva: Progress.]

\section{DAZHBOG: STAROŻYTNE SŁOWIAŃSKIE POGAŃSKIE BÓSTWO LŚNIĄCEGO NIEBA \\ Oleg V. Kutarev \\ $\infty$}

Artykuł szczegółowo analizuje obraz słowiańskiego pogańskiego bóstwa Daźboga i proponuje rewizję ugruntowanych w literaturze naukowej, ale jak się uważa, nie zawsze udanych poglądów na jego temat. Pierwszym etapem niniejszych rozważań będzie przegląd informacji na temat bóstwa, które pojawiają się w źródłach pisanych. Dziś nie ma większych wątpliwości co do tego, że Dadźbóg był znany zarówno wczesnośredniowiecznym Słowianom wschodnim (Ruś), jak i południowym (X-wieczni Bułgarzy), którzy mieli czcić Dadźboga oraz jego ojca - boga ognia Swaroga. W badaniach nad omawianym problemem szczególną uwagę zwraca się na kreowaną w XII-wiecznym piśmiennictwie ruskim rolę Daźboga jako Przodka. Pogląd ten zbudowano na gruncie zarówno średniowiecznej onomastyki, ale także obecności tego boga na Słowiańszczyźnie Zachodniej sugerujących jego prasłowiańską genezę. Rozważana jest również obecność Daźboga i prawdopodobnie pokrewnej postaci Daboga w folklorze wschodnio- i południowosłowiańskim XIX-XX wieku. Następnie szczegółowo przeanalizowano najważniejsze stereotypy historiografii dotyczące Daźboga. Przede wszystkim zaś pogląd upatrujący w nim bóstwo solarne, który komplikuje obecność w obecność w ruskim panteonie innego niewątpliwie słonecznego boga Chorsa. W oparciu o przedstawione materiały źródłowe i analizy postawiono tezę, że przesłanki, na 
których przypisuje się Daźbogowi rolę bóstwa słonecznego, są niewystarczające i wymagają innego wyjaśnienia. Takie postawienie sprawy może dowodzić, że Dadźbóg nie był tożsamy ze Swarożycem a tym samym, wbrew ogólnie przyjętym poglądom, nie był bogiem ognia. Kolejnym etapem niniejszych rozważań jest analiza etymologiczna teonimu Dadźbóg. Wykazano, że powszechna interpretacja tego imienia jako "boga dającego" nie do końca znajduje potwierdzenie w źródłach. Dość prawdopodobna jest bowiem inna etymologia, ukazująca go jako boga Ojca-Nieba, znanego wśród wielu ludów indoeuropejskich. Nie jest to pogląd nowy, jednak z upływem czasu został "zepchnięty na dalszy plan" i zupełnie niezasłużenie zapomniany w historiografii. Po drugie, należy zauważyć, że obraz Ojca-Nieba w mitologii słowiańskiej jest właściwie nieobecny, ale w kontekście badań opartych na mitologii porównawczej oraz językoznawstwie wydaje się wysoce prawdopodobny, a nawet konieczny. Jeśli więc mielibyśmy poszukiwać takiego bóstwa w wierzeniach Słowian to postacią najlepiej pasująca do roli Ojca-Nieba jest Dadźbóg. Wskazują na to: rola przodka, prawdopodobne prasłowiańskie pochodzenie oraz etymologia. Przeprowadzona analiza dowodzi też poglądu, że z upływem czasu Gromowładca, jako patron zmilitaryzowanej części społeczeństwa wysunął się na pierwszy plan i tym samym zepchnął Daźboga do drugorzędnych ról w słowiańskiej mitologii.

Oleg Vladislavovich Kutarev, Russian Christian Humanitarian Academy, St Petersburg, Russia; etnogenez@mail.ru 